\title{
Editorial: Advancements in Biomass Recalcitrance: The Use of Lignin for the Production of Fuels and Chemicals
}

\author{
Arthur J. Ragauskas ${ }^{1,2,3 *}$ and Chang Geun Yoo ${ }^{4}$ \\ ${ }^{1}$ Center for Bioenergy Innovation, Biosciences Division, Oak Ridge National Laboratory, Oak Ridge, TN, United States, \\ ${ }^{2}$ UT-ORNL Joint Institute for Biological Science, Oak Ridge National Laboratory, Oak Ridge, TN, United States, ${ }^{3}$ Department \\ of Chemical and Biomolecular Engineering, Forestry, Wildlife, and Fisheries, Center for Renewable Carbon, University of \\ Tennessee, Knoxville, TN, United States, ${ }^{4}$ Department of Paper and Bioprocess Engineering, State University of New York \\ College of Environmental Science and Forestry, Syracuse, NY, United States
}

Keywords: Lignin valorization, Biorefinery, recalcitrance, lignocellulosic biomass, characterization

\section{Editorial on the Research Topic}

\section{OPEN ACCESS}

Edited by:

Mohammad Rehan

King Abdulaziz University, Saudi Arabia

Reviewed by:

Luis Serrano,

Universidad de Córdoba, Spain

Abdul-Sattar Nizami,

Center of Excellence in Environmental Studies, King Abdulaziz University,

Saudi Arabia

${ }^{*}$ Correspondence:

Arthur J. Ragauskas

aragausk@utk.edu

Specialty section:

This article was submitted to Bioenergy and Biofuels,

a section of the journal

Frontiers in Energy Research

Received: 10 October 2018 Accepted: 18 October 2018 Published: 08 November 2018

Citation:

Ragauskas AJ and Yoo CG (2018) Editorial: Advancements in Biomass Recalcitrance: The Use of Lignin for the Production of Fuels and Chemicals. Front. Energy Res. 6:118. doi: 10.3389/fenrg.2018.00118
Advancements in Biomass Recalcitrance: The Use of Lignin for the Production of Fuels and Chemicals

The valorization of lignin has become a dominant translational research theme in biorefining in the last few years (Ragauskas et al., 2014). Historically, lignin has been sourced from kraft and sulfite pulping operations, and each of these sources provides some natural limitations to their usage. Commercially, this type of lignin has been used as a dispersant, dust suppression agent, surfactant, binder, and emulsifiers; however, most of these applications are low-value, and the markets are saturated (Gargulak and Lebo, 2000). The general limitation of these lignins is due to the presence of sulfur, extensive cross-linking, difficult process ability, purity, and low-molecular-weight profiles in the case of kraft lignin.

The next phase in lignin application is to use the intrinsic structural features of lignin to develop value-added products. Several studies have shown that lignin may be well suited for bio-based plastics and composite applications, in particular, for lignin resources isolated from biomass using an organosolv extraction protocol. Depending on the exact lignin extraction procedure used, the structure of lignin may be kept mostly intact. Several promising lignin applications include the use of oxypropylated lignin for polyurethane foams (Li and Ragauskas, 2012), inclusion into polystyrene (Henry et al., 2012), as a potential green antioxidant (Pouteau et al., 2003), or flame-retardant additive (Matsushita et al., 2017). Furthermore, lignin is also being actively developed as an adhesive for non-formaldehyde wood resins for flooring (Aracri et al., 2014), packaging, and composite wood board production (Li et al., 2018) which leverage the intrinsic reactivity between lignin and oxidoreductase enzymes, such as laccase, which catalyzes further lignin polymerization. The use of lignin has been leveraged with epoxy resins to yield printed circuit boards (Luukko et al., 2013), and for molding (Nam and Son, 2015). As reported by Stewart, the starting plant resource and lignin extraction process have a substantial impact on the resulting physical properties and the purification cost of lignin (Stewart, 2008). Finally, there is a growing interest in using lignin in the polyolefin markets (i.e., polyethylene and polypropylene) as the aromatic unit of lignin provides photo-stabilization, strength enhancement, and elongation effects ( $\mathrm{Lv}$ et al., 2011). In addition to 


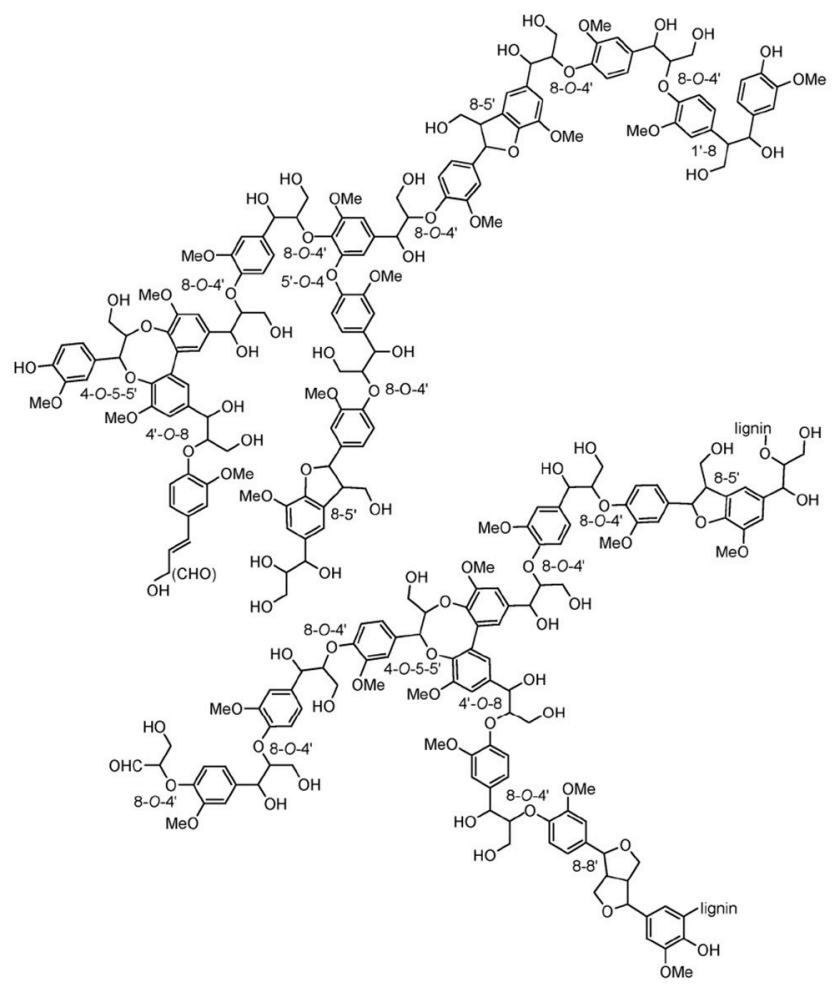<smiles>COc1cc(/C=C/CO)cc(OC)c1O</smiles><smiles>COc1cc(/C=C/CO)ccc1O</smiles>

coniferyl alcohol (SW/Ag)<smiles>OC/C=C/c1ccc(O)cc1</smiles>

coumaryl alcohol (SW/HW/Ag)

HW: hardwood

SW: softwood

$\mathrm{Ag}$ : agricultural residues

FIGURE 1 | Three phenyl propane precursors of lignin and illustration for SW lignin. (DOE, 2006).

these efforts, the conversion of lignin to chemicals and fungible fuels for ground and aviation transportation is being aggressively developed using thermal and/or catalytic processes (Ben and Ragauskas, 2011; Bi et al., 2015). As an alternative to these chemical technologies, the power of biology is also being investigated to convert lignin to fatty acids and esters using Rhodococcus (Le et al., 2017), and Pseudomonas putida for PHAs (Liu et al., 2017), to name just a few promising pathways.

In each of these applications, the structure and purity of lignin play a critical role in determining its chemical and physical properties. Lignin is one of the most complex natural polymers in regards to its chemical structure and composition. It is synthesized by enzymatic dehydrogenative polymerization of 4-hydroxyphenyl propanoid units (Figure 1). Major types of interunit linkages and the reported abundance in softwood (SW) and hardwood (HW) lignins are presented in Table 1. Also, the molecular weights of various lignins isolated from native and pretreated biomass are presented in Table 2. There are several techniques that can be used to determine the molecular weight of lignin, but one of the most commonly used methods is lignin acetylation followed by gel permeation chromatography (GPC) analysis conducted via external standards or using multi-angle laser light scattering (MALLS) (Tolbert et al., 2014).

The breadth of lignin molecular weight and its structural features have become significantly more complex as genetic engineering of the monolignol pathways have demonstrated the ability to significantly alter the S (syringyl): G (guaiacyl):
$\mathrm{H}$ ( $p$-hydroxyl) ratio in plants. In these days, the structure of lignin is widely determined using advanced $1 \mathrm{D}$ and $2 \mathrm{D}$ NMR techniques (Yoo et al., 2016b) supplemented with selected lignin functionalization techniques followed by heteronuclear single quantum coherence (HSQC) NMR techniques ( $\mathrm{Pu}$ et al., 2011). These techniques have been refined so that all the key functional groups of lignin can now be established quantitatively or semi-quantitatively. Also, they made it possible to detect the acetylation of lignin in nature and the incorporation of $p$-hydroxybenzoate, ferulate, $p$-coumaric acid, and other structures in lignin (Yoo et al., 2016a, 2017b). The presence of lignin-carbohydrate complexes (LCCs) in native and process lignin remains difficult to establish fully and yet is believed to cause challenges in the processing of lignin. This special issue highlights recent advances in lignin characterization, conversion, and valorization.

\section{AUTHOR CONTRIBUTIONS}

All authors listed have made a substantial, direct and intellectual contribution to the work, and approved it for publication.

\section{ACKNOWLEDGMENTS}

This manuscript has been authored by UT-Battelle, LLC under Contract No. DE-AC05-00OR22725 with the U.S. Department 
TABLE 1 | Reported abundance of major linkages in softwood and hardwood lignins (Chakar and Ragauskas, 2004; Zakzeski et al., 2010).

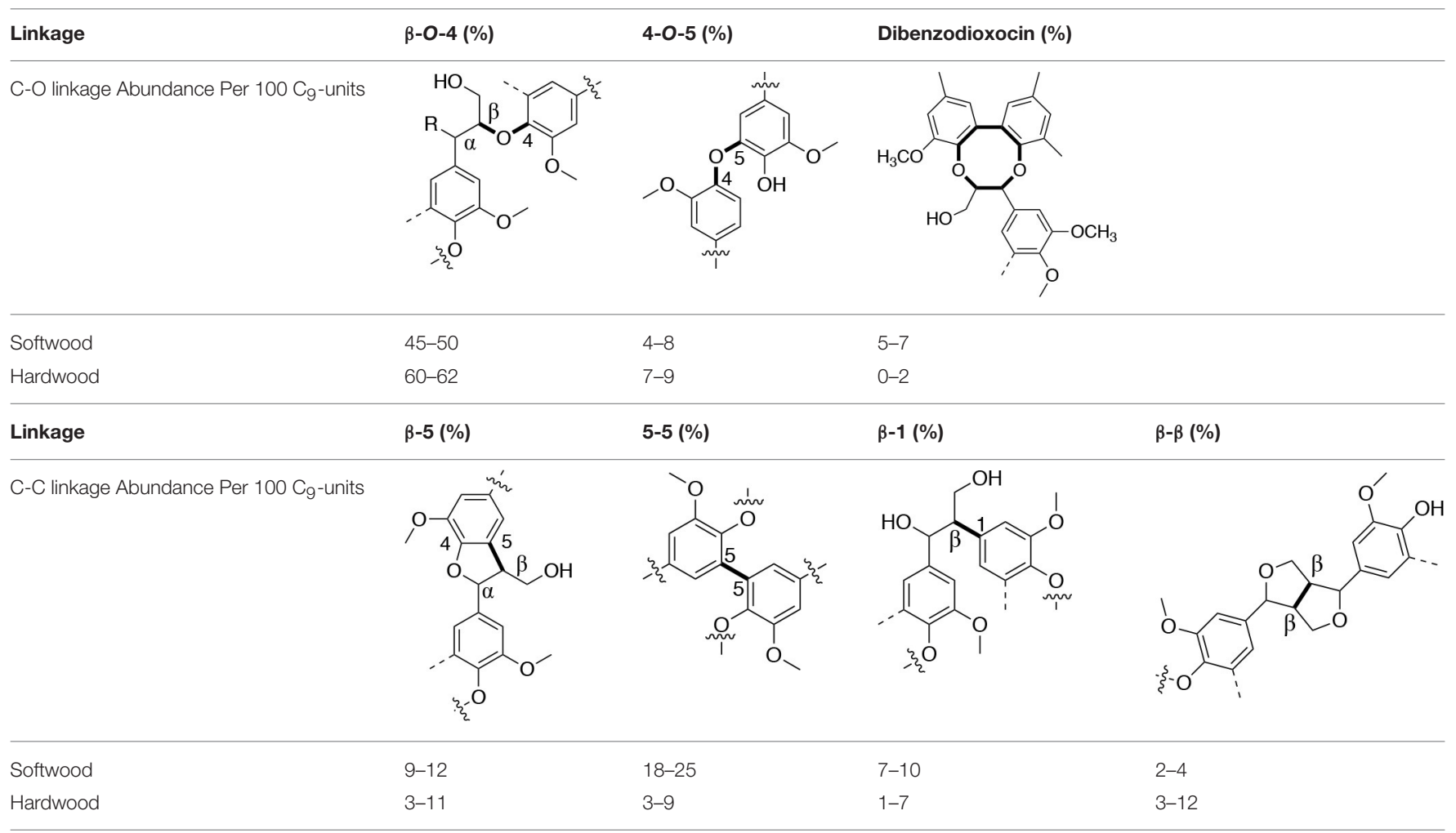

TABLE 2 | Weight-average molecular weight (Mw), number-average molecular weight $\left(\mathrm{Mn}_{\mathrm{n}}\right)$, and polydispersity index (PDI) of various lignins.

\begin{tabular}{lccc}
\hline Origin & $\mathbf{M}_{\mathbf{w}}$ & $\mathbf{M}_{\mathbf{n}}$ & PDI \\
\hline Switchgrass & 5,000 & 2,940 & 1.7 \\
Buddleja davidii & 16,800 & 7,260 & 2.3 \\
Populus & 13,260 & 5,047 & 2.6 \\
Sugarcane Bagasse & 3,176 & 1,673 & 1.9 \\
Kraft softwood lignin & 6,300 & 955 & 6.6 \\
Ammonia lignin (Corn & 3,975 & 1,827 & 2.2 \\
stover) & & & \\
Ethanol organosolv lignin & 13,800 & 8,300 & 1.6 \\
(Miscanthus) & & &
\end{tabular}

David and Ragauskas (2010); Zeng et al. (2014); Sen et al. (2015); Bezerra and Ragauskas (2016); and Yoo et al. (2016a, 2017a). of Energy. This study was supported and performed as part of the BioEnergy Science Center (BESC) and the Center for Bioenergy Innovation (CBI). The BESC and CBI are U.S Department of Energy Bioenergy Research Centers supported by the Office of Biological and Environmental Research in the DOE Office of Science. The views and opinions of the authors expressed herein do not necessarily state or reflect those of the United States Government or any agency thereof. Neither the United States Government nor any agency thereof, nor any of their employees, makes any warranty, expressed or implied, or assumes any legal liability or responsibility for the accuracy, completeness, or usefulness of any information, apparatus, product, or process disclosed, or represents that its use would not infringe privately owned rights.

\section{REFERENCES}

Aracri, E., Blanco, C. D., and Tzanov, T. (2014). An enzymatic approach to develop a lignin-based adhesive for wool floor coverings. Green Chem. 16, 2597-2603. doi: $10.1039 / \mathrm{c} 4 \mathrm{gc0} 0063 \mathrm{c}$

Ben, H., and Ragauskas, A. J. (2011). Pyrolysis of kraft lignin with additives. Energy Fuels 25, 4662-4668. doi: 10.1021/ef2007613

Bezerra, T. L., and Ragauskas, A. J. (2016). A review of sugarcane bagasse for second-generation bioethanol and biopower production. Biofuels Bioprod. Biorefin. 10, 634-647. doi: 10.1002/bbb.1662

Bi, P., Wang, J., Zhang, Y., Jiang, P., Wu, X., Liu, J., et al. (2015). From lignin to cycloparaffins and aromatics: directional synthesis of jet and diesel fuel range biofuels using biomass. Bioresour. Technol. 183, 10-17. doi: 10.1016/j.biortech.2015.02.023

Chakar, F. S., and Ragauskas, A. J. (2004). Review of current and future softwood kraft lignin process chemistry. Ind. Crops Prod. 20, 131-141. doi: 10.1016/j.indcrop.2004.04.016

David, K., and Ragauskas, A. J. (2010). Switchgrass as an energy crop for biofuel production: a review of its ligno-cellulosic chemical properties. Energy Environ. Sci. 3, 1182-1190. doi: 10.1039/b926617h 
DOE, U.S. (2006). "Breaking the biological barriers to cellulosic ethanol: a joint research Agenda," in DOE/SC/EE-0095 (U.S. Department of Energy Office of Science and Office of Energy Efficiency and Renewable Energy), 94.

Gargulak, J. D., and Lebo, S. E. (2000). "Commercial use of lignin-based materials," in ACS Symposium Series, Washington, DC.

Henry, N., Harper, D., and Dadmun, M. (2012). Optimizing noncovalent interactions between lignin and synthetic polymers to develop effective compatibilizers. Macromol. Chem. Phys. 213, 1196-1205. doi: 10.1002/macp.201100633

Le, R. K., Das, P., Mahan, K. M., Anderson, S. A., Wells, T., Yuan, J. S., et al. (2017). Utilization of simultaneous saccharification and fermentation residues as feedstock for lipid accumulation in Rhodococcus opacus. AMB Express 7:185. doi: 10.1186/s13568-017-0484-0

Li, R. J., Gutierrez, J., Chung, Y.-L., Frank, C. W., Billington, S. L., and Sattely, E. S. (2018). A lignin-epoxy resin derived from biomass as an alternative to formaldehyde-based wood adhesives. Green Chem. 20, 1459-1466. doi: 10.1039/C7GC03026F

Li, Y., and Ragauskas, A. J. (2012). Ethanol organosolv lignin-based rigid polyurethane foam reinforced with cellulose nanowhiskers. RSC Adv. 2, 3347-3351. doi: 10.1039/c2ra00646d

Liu, Z.-H., Olson, M. L., Shinde, S., Wang, X., Hao, N., Yoo, C. G., et al. (2017). Synergistic maximization of the carbohydrate output and lignin processability by combinatorial pretreatment. Green Chem. 19, 4939-4955. doi: 10.1039/C7GC02057K

Luukko, K., Kahari, H., and Fors, S. (2013). A Biodegradable Circuit Board, WO2013144420. World Intellectual Property Organization.

Lv, X. Y., Gao, Z. H., Zhang, Y. H., and Di, M. W. (2011). Mechanical study and microscopic characterization of lignin/PE composites. Adv. Mater. Res. Trans. Tech. Publ. 335-336, 191-194. doi: 10.4028/www.scientific.net/AMR.335-336.191

Matsushita, Y., Hirano, D., Aoki, D., Yagami, S., Takagi, Y., and Fukushima, K. (2017). A biobased flame-retardant resin based on lignin. Adv. Sustain. Syst. 1:1700073. doi: 10.1002/adsu.201700073

Nam, K. G., and Son, J. I. (2015). Wood Plastic Composites and Manufacturing Method Thereof, WO2013151287. World Intellectual Property Organization.

Pouteau, C., Dole, P., Cathala, B., Averous, L., and Boquillon, N. (2003). Antioxidant properties of lignin in polypropylene. Polym. Degrad. Stab. 81, 9-18. doi: 10.1016/S0141-3910(03)00057-0

$\mathrm{Pu}, \mathrm{Y} ., \mathrm{Cao}, \mathrm{S}$., and Ragauskas, A. J. (2011). Application of quantitative 31P NMR in biomass lignin and biofuel precursors characterization. Energy Environ. Sci. 4, 3154-3166. doi: 10.1039/clee01201k

Ragauskas, A. J., Beckham, G. T., Biddy, M. J., Chandra, R., Chen, F., Davis, M. F., et al. (2014). Lignin valorization: improving lignin processing in the biorefinery. Science 344:1246843. doi: 10.1126/science. 1246843
Sen, S., Patil, S., and Argyropoulos, D. S. (2015). Methylation of softwood kraft lignin with dimethyl carbonate. Green Chem. 17, 1077-1087. doi: 10.1039/C4GC01759E

Stewart, D. (2008). Lignin as a base material for materials applications: chemistry, application and economics. Ind. Crops Prod. 27, 202-207. doi: 10.1016/j.indcrop.2007.07.008

Tolbert, A., Akinosho, H., Khunsupat, R., Naskar, A. K., and Ragauskas, A. J. (2014). Characterization and analysis of the molecular weight of lignin for biorefining studies. Biofuels Bioprod. Biorefin. 8, 836-856. doi: $10.1002 / \mathrm{bbb} .1500$

Yoo, C. G., Kim, H., Lu, F., Azarpira, A., Pan, X., Oh, K. K., et al (2016a). Understanding the physicochemical characteristics and the improved enzymatic saccharification of corn stover pretreated with aqueous and gaseous ammonia. Bioenergy Res. 9, 67-76. doi: 10.1007/s12155-015-9662-6

Yoo, C. G., Li, M., Meng, X., Pu, Y., and Ragauskas, A. J. (2017a). Effects of organosolv and ammonia pretreatments on lignin properties and its inhibition for enzymatic hydrolysis. Green Chem. 19, 2006-2016. doi: $10.1039 / \mathrm{c} 6 \mathrm{gc} 03627 \mathrm{ai}$

Yoo, C. G., Pu, Y., Li, M., and Ragauskas, A. J. (2016b). Elucidating Structural Characteristics of biomass using solution-state 2D NMR with a mixture of deuterated dimethylsulfoxide and hexamethylphosphoramide. ChemSusChem 9, 1090-1095. doi: 10.1002/cssc.201600135

Yoo, C. G., Yang, Y., Pu, Y., Meng, X., Muchero, W., Yee, K. L., et al. (2017b). Insights of biomass recalcitrance in natural Populus trichocarpa variants for biomass conversion. Green Chem. 19, 5467-5478. doi: 10.1039/C7GC 02219K

Zakzeski, J., Bruijnincx, P. C., Jongerius, A. L., and Weckhuysen, B. M. (2010). The catalytic valorization of lignin for the production of renewable chemicals. Chem. Rev. 110, 3552-3599. doi: 10.1021/cr900354u

Zeng, J., Tong, Z., Wang, L., Zhu, J., and Ingram, L. (2014). Isolation and structural characterization of sugarcane bagasse lignin after dilute phosphoric acid plus steam explosion pretreatment and its effect on cellulose hydrolysis. Bioresour. Technol. 154, 274-281. doi: 10.1016/j.biortech.2013.12.072

Conflict of Interest Statement: The authors declare that the research was conducted in the absence of any commercial or financial relationships that could be construed as a potential conflict of interest.

Copyright $\odot 2018$ Ragauskas and Yoo. This is an open-access article distributed under the terms of the Creative Commons Attribution License (CC BY). The use, distribution or reproduction in other forums is permitted, provided the original author(s) and the copyright owner(s) are credited and that the original publication in this journal is cited, in accordance with accepted academic practice. No use, distribution or reproduction is permitted which does not comply with these terms. 